Hard Law, Soft Law and Self-regulation: Seeking Better Governance for Science and Technology in the EU Maria Eduarda Gonçalves Maria Inês Gameiro WP n. $\cong 2011 / 18$ 


\section{DINAMIR'CET}

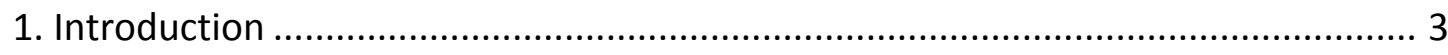

2. The ambiguous frontiers of soft law, self-regulation and co-regulation................. 5

3. Comparing EU regulatory tools for several technologies ................................... 12

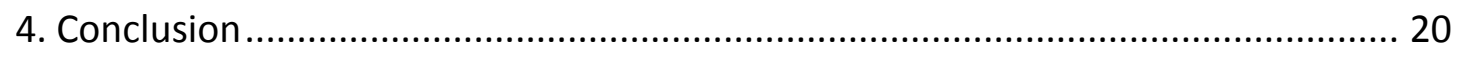

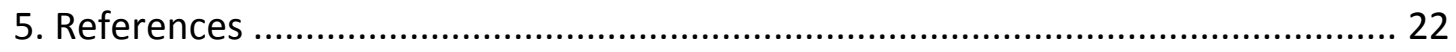




\title{
Hard Law, Soft Law and Self-regulation: Seeking Better Governance for Science and Technology in the EU ${ }^{1}$
}

\begin{abstract}
There is a pretty wide belief that 'soft law' together with self-regulation provide suitable regulatory tools for emerging science and technology (S\&T), possibly better tools than 'hard law' to cope with the need for both flexibility and adjustment to novelty and prevailing uncertainties. Soft law and self-regulation, it is argued, may also respond more adequately to increased pressure for opening up regulation to new governance modes arising from mounting public unease with S\&T in ethically and socially sensitive or controversial domains. However, doubts have also accompanied the use of soft law, as well as of self-regulation: although often designed to enhance more active participation and dialogue with the civil society, and ultimately to increase decision-making legitimacy, they are perceived as lacking transparency and accountability too.
\end{abstract}

Our overview of the EU regulatory response to various emerging technologies in recent decades led us to the conclusion that the overall picture is more complex than these beliefs may suggest. Actually, soft law and self-regulation have been resorted to as regulatory tools mostly as preparatory or complementary tools to 'hard law'.

Keywords: soft law, self-regulation, governance, science \& technology.

\footnotetext{
${ }^{1}$ This paper draws on research carried out under 'The Landscape and Isobars of European Values in Relation to Science and New Technology (Value Isobars)' (2009-2011), a project fundled by the European Union's the 7th Framework Programme for Research and Development.
} 


\section{Introduction}

In the past, science was one of those fields that, like art or friendship, were regarded as alien to market mechanisms as well as immune to state law. Research freedom and the free circulation of scientific data stood among the basic principles differentiating the codes of the scientific community, and were thought to be spontaneously generated and controlled within the scientific order. Yet the social context underlying this model of the relationship between science and the law has changed profoundly throughout the $20^{\text {th }}$ century, up to present-day. Many scientific disciplines now have profound impact on the economy, work, the environment and health, and even our personal life. Moreover, the modern connotation of science with progress has lost some ground as scientific research and technological development became increasingly associated not only with economic growth and welfare but also with new kinds of individual and collective risk, particularly in areas such as the biosciences and biotechnology or information technologies. Recognition of this trend has brought growing regulatory action by public authorities, both at national or international levels, including European level. Behind this effort has been the aim of safeguarding fundamental human rights, as well as the public interest, in particular the quality of the environment, public health and public safety. The normative framework of science and technology has been reshaped as a result. The old scientific order has declined as various dimensions of scientific practices have come under legall jurisdiction. The question, however, arises of what the most appropriate scope and methods are for the regulation of emerging science and technology.

The dynamics of scientific research, requirements for autonomy and flexibility, ethical considerations brought by highly sensitive domains, and above all the principle of the freedom of research account for the importance lent to self-regulation as the logical regulatory framework from very early on by the researchers themselves. More recently, the notion has also gained supporters that soft law, which means non-binding norms produced by law-making bodies, might better serve the needs and purposes of science than legislative modes of topdown, hierarchical-based authority of the state and other public actors (EC 2007, 52). Today, this idea is closely related to the belief that governance supported by multiple authorities, which are not necessarily public and state-centred and are based on a fluid system of power sharing, may be facilitated by soft law rather than hard law (Mörth 2004; 2005). 'In systems of government the law is hard whereas it is soft in systems of governance', Mörth $(2005,2)$ argues. Alleged motivations for using soft law to govern S\&T include uncertainties in rapidly developing technological or scientific fields; social uncertainty and controversy in sensitive areas; and lack of agreement within or among governments. 
There is indeed a rather widespread belief, in political as well as in scientific circles, that nonbinding governance or soft law, as well as codes of practice, guidance and reporting measures, provide more suitable regulatory tools for scientific research and the development and use of emerging technologies than hard law in the form of legislation, a view described often as the 'new governance of science' (Kurath 2009, 89).

The contextualisation of societal concerns in scientific research has been linked to the concept of 'social robustness'. Regulatory and deliberative oriented governance approaches tend to be socially robust when 'they consider and include external contexts', like 'acceptability by individuals groups and societies', 'generate stability, have been infiltrated and improved by social knowledge, and are subject to frequent testing, feedback and improvement' (Kurath 2009, 90; Nowotny et al. 2001). It is assumed that soft law and self-regulation may respond more easily to increased pressures for opening up policy-making due to mounting public unease with particular scientific and technological developments. At least, this seems to be the perspective coming from official documents linking soft law, self-regulation as well a co-regulation to a more participative society in S\&T regulation and governance ${ }^{2}$.

In the European Union (EU), the latest adoption by the European Commission (EC) of the recommendation for a code of conduct for nanosciences and nanotechnologies appears to support this assumption. European Parliament's resolutions on cutting-edge research and technology such as human cloning, electromagnetic fields and related health concerns, human egg cell trade or respect for fundamental rights on the Internet offer additional illustrations of this. Counter examples of the use of legislation are EU directives and regulations on GMOs or the EU regulation on biometrics in passports and travel documents.

Hence some empirical and normative questions arise:

- Do EU institutions prefer soft law to hard law for regulating scientific research and technological development or does soft law function rather as a preparatory phase leading to hard law?

- What are the motivations and the circumstances under which EU institutions have recourse to soft law as a regulatory tool? Is soft law used chiefly to address ethically or socially sensitive and controversial issues in science and technology?

- What role does the EU assign to self-regulation as a means of regullating science and technology?

- Have soft law instruments been working as guarantees for a more democratic, inclusive governance of science and technology or are they rather a manifestation of deregulatory trends

\footnotetext{
${ }^{2}$ See EC 2001 and EC 2009b. On citizen participation in EU governance of new technologies, arguing that 'it is not truly informed by human rights', see Flear, Vakulenko 2010.
} 
involving the private definition of applicable rules, in other words, a deliberate move by the EU policy-makers and legislators to reduce constraints on scientific research and technological development?

These issues need to be seen in the context of the wider EU agenda on regulation and governance, particularly the so-called 'better regulation' agenda and explicit EU concerns about opening regulation up to stakeholders and society at large.

Following an overview of the genesis and conceptual debate around soft law and its rapport with self-regulation, we will examine recent trends in science and technology regulation within the EU to determine the part played by both soft and hard law, as well as codes of conduct, and the motivations underlying the choice of each regulatory instrument, and offer some possible explanations for the trends identified. For the purposes of the analysis, a few case studies deemed especially illustrative were selected: nanotechnologies, human cloning, biometrics and genetically modified organisms (GMO).

\section{The ambiguous frontiers of soft law, self-regulation and co-regulation}

Despite its widespread use in academic literature, soft law is a somewhat imprecise analytical category. ${ }^{3}$ Most often, the term encompasses a variety of normative, non-binding instruments emanating from law-making bodies including resolutions, recommendations, guidelines, communications, notices, etc. However, soft law has also been employed lato sensu to encompass not only public, top-down instruments, but also self-regulation by private nongovernmental organisations, particularly in the form of codes of conduct (Mörth 2005).

The lack of binding force is the main feature distinguishing soft from hard law (Senden 2004, 112). Authors agree to define soft law as rules of conduct with no strict legally binding force, but which nevertheless may have or are intended to have practical and even legal effects (Snyder 1993, 198; Senden 2004, 112; 2005, 23). Though issued by law-making authorities, soft law rules do not comply with constitutional and other formalities required for the rule to be legally binding (Gersen, Posner 2008, 6), neither are they enforceable nor sanctionable by the means of responsibility and accountability modes characteristic of hard law (Wellens, Borchardt $1989,274)$. Yet, they are potentially enforceable, and should not be regarded as merely ethical or moral in nature (Andorno 2007).

References to soft law in the context of European law emerged timidly in the 1980s (Senden 2004, 109). The soft law approach subsequently expanded across several fields of EU

\footnotetext{
3 Lawyers are sometimes 'more inclined to treat soft law as an analytical concept whereas the social scientists tend to treat it as an empirical phenomenon' (Mörth 2005, 6).
} 
jurisdiction from financial management and taxation to social policy, from workers' rights to competition policy. ${ }^{4}$ Article 288 of the Treaty on the Functioning of the European Union (formerly Article 249 of the Treaty of the European Community) now includes recommendations and opinions among the 'legal acts of the Union', stating that they 'have no binding force'. The open method of co-ordination, a governance strategy used in areas such as employment and social policies, offers an additional example of a soft law approach. ${ }^{5}$

As pointed out above, the notion of soft law has also been applied to a different kind of normative instrument, i.e. codes of conduct adopted mainly by private non-governmental entities, more properly termed self-regulation. The EU 'Inter-institutional Agreement on Better Law Making' defined self-regulation as 'the possibility for economic operators, the social partners, non-governmental organisations or associations to adopt amongst themselves and for themselves common guidelines at European level' (Inter-institutional Agreement 2003, 3). ${ }^{6}$ Codes of conduct within the EU are spreading too. In addition to codes of conduct set by multinationals and professional associations ${ }^{7}$, there has been an upsurge of codes in the areas of consumer and environmental protection (EESC 2005, 16, 17). Though admitting that selfregulation can be a tactic to avoid public regulation, the European Economic and Social Committee (EESC) welcomed it as a flexible and dynamic regulatory tool suitable for areas that are continuously shifting and evolving, and capable of encouraging 'a sense of co-responsibility among economic and civil society stakeholders' (EESC 2005, 22). Self-regulation increasingly appears to involve input from both the public and the private spheres. The EESC underlined that the organization of private interests 'cannot be done in a way that might appear damaging to the public interest' and must take place in an atmosphere of respect for fundamental values (EESC 2005, 19). A relatively novel development is that European legislation now explicitly recommends the enactment of codes of conduct in an important move towards the complementarity of both hard and soft law with self-regulation.

The connection between hard law and self-regulation may be perceived clearly in the phenomenon of co-regulation. Emphasised by EU institutions along with self-regulatory instruments, co-regulation has been defined as 'the mechanism whereby a Community

\footnotetext{
${ }^{4}$ An example of a code of conduct is the Code of Ethical Criteria adopted by the members of the Executive Board of the European Central Bank. On the growth of soft law instruments in competition law see Stefan 2008.

${ }^{5}$ Cf. EC 2001 and Trubek et al. 2005.

${ }^{6}$ See also the Information Report adopted by the EESC in February 2005 on the Current state of coregulation and self-regulation in the Single Market CESE 1182/2004 fin of 10.02.2005, 11. A useful database with self and co-regulation initiatives can be found in the European Economic and Social Committee website: http://www.eesc.europa.eu/?i=portal.en.self-and-co-regulation-enter-the-database.

7 These codes of conduct typically include codes of ethics addressing fundamental social values or the commitment to comply with shared principles. They are often set according to the guiding principles drawn up by the OECD or the code of conduct for multinationals from the European Parliament (Howitt report, January 1999) (EESC 2005, 16, 17).
} 
legislative act entrusts the attainment of the objectives defined by the legisllative authority to parties which are recognised in the field (such as economic operators, the social partners, nongovernmental organisations, or associations)' (Inter-institutional Agreement 2003, 3). Coregulation implies the prior involvement of a legislative authority, its main feature being the active participation of both public and private actors in regulation (Verbruggen 2009, 425, 426, 429). Co-regulation has also been perceived as enhancing the legitimacy of EU governance.

Unlike soft law as such, self-regulation is not law in a strict sense, 'which is not to say ... that it can be seen as detached from the law' (Senden 2005, 12). Indeed, theories of legal pluralism tend to broaden the concept of law beyond 'command and control'. Rules of law, according to Mireille Delmas-Marty, can be seen as landscapes composed of normative space, time and order. Nowadays, 'in this confused landscape, rules of law seem to spring up everywhere, at any time and in every direction: a spatial, temporal and conceptual relativity scrambles all the usual reference points' giving place to a 'denationalised' normative space, 'destabilised' time and a 'delegalised' order' (Delmas-Marty 2002, 31). For legal pluralists, rules of conduct adopted by infra-national (and supra-national) organisations also constitute law (Carbonnier 1979, 213 ff). Carbonnier's well-known definition states that 'law is a mere lining, covering the external surface of social relationships' (Carbonnier 1965, $279 \mathrm{ff}$ ). In its 'soft' version, law is also closer to self-regulation to the extent that it lacks enforcement means or sanctions.

In fact, the ambiguities at the frontiers of the concepts of soft law, self-regulation and law as such should not be overlooked. While in practice self-regulation may be sensed by its instigators or addressees as compulsory (e.g. professional codes of conduct), 'hard law' is sometimes mostly 'hortatory', for example when it proclaims very general and abstract principles, its effectiveness being conditional upon implementation (Gersen, Posner 2008, 21; Fauré 2011). Besides, the notion of soft law covers a diverse set of normative instruments with varying degrees of authority and influence. The same type of instrument, a communication or a recommendation, emanating from the same institution, the EC for instance, may be considered 'soft law' or a mere political declaration depending on their stronger or weaker language and the context of their adoption or implementation. A case-by-case analysis is therefore required, examining the purpose and objective of the specific instrument, particularly whether it performs a pre-legislative function (preparatory or informative, such as green and white papers), strategic guidance (e.g. action plans) or if it has a true normative character, even if not binding, stating principles, norms or setting some interpretative framework. Some instruments may have more than one function: this is the case of EC communications, which sometimes provide guidance for the application of existing EU law, but can also serve to prepare future EU law (Senden 
2005, 23-24). The complexity of the issue calls for a 'pragmatic' approaclh, since 'different domains have different needs' (Trubek et al. 2005, 3). The ambiguities at the frontiers of the concepts of soft law, self-regulation and law point to "hybrid" constellations in which both hard and soft processes operate in the same domain and affect the same actors' (Trubek et al. 2005, 3, 4).

Let us recall that the notion of 'soft law' first emerged in the field of international law where non-binding instruments appeared as a natural consequence of an international society composed of sovereign entities (Di Robilant 2006). In 1950, Hersch Lauterpacht regretted that states had only agreed to the terms of the Universal Declaration of Human Rights because this Declaration would not bind them (von Bernstorff 2008, 905). International relations continue to offer a rich ground for debate about both soft law and the legal nature of international conventions, non-binding treaties and other agreements. From the late 1990s and the early 2000 s, the attention paid to soft law reflected 'the increasing awareness of globalisation and the importance of non-state actors, but also how globalisation makes traditional law making more problematic when states are embedded in various formal and informal organisations' (Mörth 2004, 4).

EU law departs from public international law due to its direct effect, not only on states, but also on individuals. Nevertheless, the part played by soft law in the EU legal system is growing, as already pointed out. How may this apparent paradox between EU law as a supranational legal framework and the growing role of soft law be accounted for?

Mörth and Trubek recognise that the concept of soft law fits with the analysis of the EU as a system of multilevel governance (Mörth 2004; Trubek et al. 2005). Soft law can also facilitate the involvement of stakeholders and the public in consultative processes which lead to EC green or white papers as preparatory stages for EU decision-making, and in this way enhance EU legitimacy (Senden 2004, 224; Trubek et al. 2005, 12). This attribute has been underlined by several opinions from the EESC and is consistent with the desired proximity of European institutions to citizens, which has been emphasised in the last few decades. Lack of agreement between Member States and the lack of a formal EU jurisdiction can also be bypassed more easily through soft law originating from European institutions. In all these circumstances, soft law will mainly operate as a preparatory stage for legislation, a feature described as 'incrementalism', the 'first step on the path to legally binding agreements or hard law' (Trubek et al. 2005, 12). To the extent that soft law features pre-regulatory or bottom-up regulatory action, it may also be regarded as a favourable and flexible vehicle for translating ethical, values-related concerns linked to the impacts of science and technology. 
The use of soft law in the EU may be related to the objectives announced in the EC's White Paper on European Governance, published in 2001. The White Paper and other official documents addressing a 'better regulation agenda' point toward greater use of different policy tools, particularly regulations, framework directives, guidelines, recommendations, coregulatory mechanisms, and even self-regulation to be chosen on a case-by-case basis. In this area, the EC has shown its concern 'to react more rapidly to changing market conditions and new problems by reducing the long delays associated with the adoption and implementation of Community rules' (EC 2001, 20). Improving efficiency converges with a concern with public involvement and participation in the wider context of governance set up in the White Paper as 'rules, processes and behavior that affect the way in which powers are exercised at European level, particularly as regards openness, participation, accountability, effectiveness and coherence' (EC 2001, 8). According to the Commission, 'investment in good consultation "upstream" may produce better legislation which is adopted more rapidly and easier to apply and enforce' (EC 2001, 20). ${ }^{8}$ Yet, the White Paper attracted criticism around Europe from those who regard the use of 'new tools' such as co-regulation and the open-method of coordination as steps back in the integration process.

The pros and cons of soft law have indeed been debated. The European Parliament cautioned against the dangers of relying too greatly on soft law, particularly when authority for the design of particular soft law instruments is delegated to bodies lacking democratic control. Soft law may, the European Parliament alerted, also 'become a tool in the hands of a few powerful or privileged players that sidestep constraints of the legal process and that view it as a powerful alternative to lobbying elected representatives'. The Parliament also admitted that soft law does not 'provide full judicial protection' (EP 2007, paragraph D), brings 'confusion and insecurity' (EP 2007, paragraph N) and generates a 'public perception of "superbureaucracy" with no democratic legitimacy' (EP 2007, paragraph Y).

One of the drawbacks of soft law certainly is its 'loose' character due to lack of binding force. However, soft law also has a persuasive characteristic, namely the threat that if it does not meet the objectives set by the European institutions, they can use hard law. This notion can be seen clearly in the White Paper on Governance: soft law does not preclude the adoption of hard law if the former does not prove to be effective (EC 2001, 21). One additionall difficulty may be lack of transparency, since soft law is not always drawn up and published through a mandatory process. This should be balanced against the trend to publish soft law acts through the Internet and a growing awareness of the need for consultation and dialogue (Senden 2004, 496).

\footnotetext{
8 'Upstream engagement' has been often associated with the new governance of science and technology (Kurath 2009, 89).
} 
Indeed, the role of soft law is far from consensual in the EU legal and institutional system. Though the EC has favoured soft law as one policy tool among others, the European Parliament has voiced severe criticism of soft law. Considering the distinction between dura lex/mollis lex to be conceptually aberrant, and therefore to be discarded, the Parliament has argued that the extensive use of soft law would mean a shift from the single Community model to that of a traditional international organisation. 'So-called soft law instruments, such as recommendations, green and white papers or Council conclusions, do not have any legal value or binding force', the European Parliament pointed out (EP 2007, paragraphs B and C). These instruments, 'which can be used as interpretative or preparatory tools for binding legislative acts, should neither be treated as legislation nor be given any norm-setting effectiveness' (EP 2007, paragraph M). 'Only where the Treaty expressly provides for them, soft law instruments are legitimate, provided that they are not used as a surrogate for legislation', the Parliament concluded. For the Parliament, the EU Commission's 'better legislation agenda' should not be subverted to allow the EU executive to legislate by means of soft law, thereby potentially undermining the European legal order, avoiding the involvement of the democratically elected Parliament and the legal review by the Court of Justice and depriving citizens of legal remedies. However, both the Commission and the European Court of Justice (ECJ) have admitted that soft law may produce legal effects. Soft law (e.g. notices and guidelines for competition policy) was considered by the ECJ to have legal effects to be taken into account in deciding cases submitted for its judgment, when this serves the enforcement of certain superior principles of law (Ştefan 2008, 753 ff). In Commission v Germany, Advocate General Mazak acknowledged the legal effects of soft law. ${ }^{9}$

Strikingly, self-regulation has not raised similar controversy. While critical of soft law, the Parliament acknowledged that codes of conduct constitute important elements of selfregulation' (EP 2007, paragraph 12). By doing so it distinguished between soft law and selfregulation, as did the White Paper, while stressing the need to 'combine formal rules with other non-binding tools such as recommendations, guidelines or even self-regulation' as means towards a 'less top-down approach' in EU law making (EC 2001, 4, 20, 22; Senden 2005).

Codes of conduct and codes of practice are common in the scientific community. ${ }^{10}$ European law explicitly recommends the enactment of codes of conduct in a move towards

\footnotetext{
${ }^{9}$ Opinion of Advocate General Mazak delivered on 12 November 2009, Case C-518/07, Commission $v$ Germany [2010] ECR P-I01885, § 11, http://eur-law.eu/EN/Opinion-Mr-Advocate-General-Mazakdelivered-12-November,395943,d.

${ }^{10}$ Examples of codes of conduct in science and technology include the 'Code of Conduct regarding Genetic Modification' (http:/www.rabobank.com), the Ethical Guidelines for the use of human embryonic or foetal tissue for experimental and clinical neurotransplantation and research' of the Network of European CNS Transplantation and Restoration (NECTAR) (http://www.nesu.mphy.lu.se/nectar/eth.1.html), the
} 
complementarity of hard and soft law with self-regulation. The European Charter for Researchers and the Code of Conduct for the Recruitment of Researchers was the object of an EC Recommendation in $2005^{11}$. A code of conduct on confidentiality, potential conflict of interest, and processing of personal data has been recommended for adoption by the European Scientific Council (EC 2011, Article 1, no 5). Directive 95/46/EC, the Data Protection Directive, also encourages codes of conduct by Member States and the Commission 'intended to contribute to the proper implementation of the national provisions adopted by the Member States pursuant to this Directive, taking account of the specific features of the various sectors' (Article 27). A further illustration is the EC Recommendation on a code of conduct for responsible nanosciences and nanotechnologies research (EC 2008), to be addressed below. ${ }^{12}$ Codes of conduct adopted by scientific researchers typically regulate matters like scientific fraud, misuse or misconduct. However, as the social relevance of scientific activities grows, professional and ethical misconduct by scientists has come to the core of the relationship between society and science, calling for more than mere self-regulation (EESC 2001, paragraphs $4.9,4.9 .1) .^{13}$

As a matter of fact, EU institutions welcome self-regulation as a tool for citizenoriented governance. In a number of documents, particularly, 'Current state of co-regulation and self-regulation in the Single Market', the 'Opinion on better law-making' and the 'Opinion on making European citizenship visible and effective', the EESC favoured 'socio-professional selfregulation and co-regulation in all areas of direct relevance to civil society' whereby the 'socioprofessional actors themselves are not only consulted but are actually involved in defining economic or social rules which concern them directly' (EESC 2006b, 163, 168). The other side of the coin, though, may be that self-regulation is 'representing groups one-sidedly' (Héritier 2001, 6). Despite its generally favourable attitude towards self-regulation, the need has been underlined to prevent self-regulation from bypassing EU law in areas 'that very directly affect

'Memorandum on Scientific Integrity' from the All European Academies (ALLEA) (http://www.allea.org). At the national level examples are the Deutsche Forschungsgemeinschaft (DFG)' 'Proposals for Safeguarding Good Scientific Practice' (http://www.dfg.de/aktuelles_presse/reden_

stellungnahmen/download/self-regulation_98.pdf), in Germany, and the Uppsala Code of Ethics for Scientists (http://user.it.uu.se/ pugwash/Etik/uppsalakodex.html), in Sweden.

$11 \mathrm{http}: / /$ ec.europa.eu/eracareers/pdf/am509774CEE EN E4.pdf. According to the European Charter for Researchers, 'Researchers should adhere to the recognised ethical practices and fundamental ethical principles appropriate to their discipline(s) as well as to ethical standards as documented in the different national, sectoral or institutional Codes of Ethics' (EC 2005, 11).

${ }^{12}$ European Parliament resolution of 24 April 2009 on regulatory aspects of nanomaterials (2010/C 184 E/18), P6_TA (2009) 0328 (10).

13 The OECD addressed scientific misconduct (fabrication, falsification and plagiarism) as a problem that 'damages the scientific enterprise' and 'undermines the trust of citizens in science and government', recommending the adoption of codes of conduct covering 'traditional ethics issues (e.g., rights of human subjects, handling of experimental animals, philosophical/moral aspects of research in human reproductive biology, defence-related research)'. See OECD, 'Best Practices for Ensuring Scientific Integrity and Preventing Misconduct', generally points to science-based regulation, p. 1 and 13. 
health and safety, and more broadly in the case of services of general interest' (EESC 2005, 23). In the end, despite the specific role recognised for both soft law and self-regulation, they tend to be understood against the backdrop of European law itself; in other words, their scope and practical effects as regulatory tools ultimately appear to draw their legitimacy and influence from EU 'hard law'.

Against this somewhat hazy background, what trends may one discern in the EU regulation of nanotechnologies, biometrics, human cloning and genetically modified organisms? In the following section, we review and compare the current EU normative frameworks in these domains to determine the part played by hard law and soft law, as well as self-regulation and coregulation, and discuss the extent to which they enable more or less open and participative governance.

\section{Comparing EU regulatory tools for several technologies}

Nanosciences and technologies are among novel scientific and technological developments that appear difficult to frame in formal legislation: to begin with, the scope of the field is still unclear, including their potential applications which range from chemicals to electronics, food or cosmetics, rendering it problematic to adopt a single regulatory framework (European Parliament 2010, paragraph R; paragraph 10) ${ }^{14}$. Mirroring the process of GMOs, States and international institutions hesitate with respect to the appropriate way of regulating nanotechnologies ${ }^{15}$. Leading public investors, such as United States and Australia, have not enacted nano-specific legislation yet ${ }^{16}$. Options can range from hard law to 'a combination of self-regulation and government coordination and monitoring' (Reynolds 2003, 201), showing that the 'regulation of nanotechnology manufacturing processes and products presents a myriad of complex policy and regulatory challenges for public and private sector actors', including matters of "product safety, privacy and civil liberties, occupational health and safety, intellectual property, international law and environmental law' (Bowman, Hodge 2007, 35, 36).

The EU chose to regulate scientific research and technological development in this area by means of a soft law instrument, a recommendation from the EC proposing a self-regulatory instrument in the form of a code of conduct. The code of conduct for responsible nanosciences and nanotechnologies research is addressed to all stakeholders involved in nanotechnologies,

\footnotetext{
${ }^{14}$ For a comprehensive report on nanosciences and nanotechnologies see Royal Societty \& Royal Academy of Engineering 2004.

${ }^{15}$ See Bowman, Hodge 2007 on the parallel between nanotechnologies and GMOs, namely on the debate concerning product or process-based approaches and national and international gaps and overlaps.

${ }^{16}$ A bill to amend the Federal Food, Drug and Cosmetic Act was introduced in the Congress in 2011 (Nanotechnology Regulatory Science Act).
} 
i.e. 'Member States, employers, research funders, researchers and more generally all individuals and civil society organisations' (EC 2008, 5) ${ }^{17}$. The EC Recommendation also emphasises the need for Member States to 'encourage the voluntary adoption of the Code of Conduct by relevant authorities, employers, research funding bodies, researchers, and any individual or civil society organization'. The code was presented as 'an appeal and a driving force for Member States and the research community to provide a tangible contribution to the good governance of technology' (EC 2007c, 2).

The public consultation carried out under the auspices of the EC before the adoption of the Recommendation evidenced a wide consensus on the code of conduct as the appropriate regulatory tool in those circumstances. The main concern was to subject research and development in this field to a set of ethical principles. ${ }^{18}$ In its Opinion on the 'Communication from the Commission: Towards a European Strategy for Nanotechnologies', the EESC also related openness and public dialogue to the need to clarify the ethical principles which were applicable:

'There must be an on-going and scientifically well-founded dialogue with the public. ... History has taught us that, very often, fear and concern regarding new products are born more out of ignorance than reality. This is one of the reasons why the EESC hopes that there will be an unceasing and direct connection between research results and universally recognised ethical principles' (EESC 2005b, paragraphs 8.12 and 8.12.1, original emphasis).

Stakeholders who adhere to the code should ensure that 'N\&N research is undertaken in the Community in a safe, ethical and effective framework' (EC 2008, 5). Industry also acknowledged ethical concerns 'conscious of the importance of societal support to Nanotechnologies in order to gain trust and avoid GMO block' (EC 2007d, 3). The European Parliament recently sent out an appeal to manufacturers of nanomaterial to comply with the

\footnotetext{
17 See also Council Meeting No. 2832, 22-23 November 2007, http://www.consilium.europa.eu/App/TransparencyCouncil/default.aspx?lang=en\&cmsid=1119\&pagenum =25. http://www.consilium.europa.eu/uedocs/cms data/docs/pressdata/en/intm/97225.pdf.

18 The Council's conclusions of 25-26 September 2008 stressed that principles of responsible research warranted special attention in this area (Council Conclusions 2008, 34). Six major principles are proclaimed by the Recommendation: sustainability, precaution, inclusiveness, excellence, innovation and accountability. Initially, the Consultation Paper emphasised precaution, inclusiveness and integrity $(3,4)$. There were numerous proposals on principles. Examples include 'transparency' (proposed by civil society organizations) and 'Sustainable Development, Transparency, Openness, Security, Safety, Quality of Science, Responsibility, Anticipation and the Precautionary Principle in line with Progress' (proposed by industry) $(3,4)$. In fact, though $100 \%$ of the policy- makers consulted agreed with the principles, $0 \%$ of civil society agreed with them (EC 2007d, 2). In the remaining categories, $79 \%$ of Researchers and 54\% of Industry agreed with the proposed principles (EC 2007d, 2).
} 
code of conduct $^{19}$ (EP 2010, paragraph Z), considering that 'the likely convergence of nanotechnology with biotechnology, biology, cognitive sciences and information technology raises serious questions relating to ethics, safety, security and respect for fundamental rights' (EP 2010, paragraph Y). The Parliament also called for a new opinion by the European Group on Ethics in Science and New Technologies as well as for a continued 'EU-wide public debate on nanotechnologies and nanomaterials and on the regulatory aspects of nanomaterials' (EP 2010, paragraph 23$)^{20}$.

Though emphasising the voluntary nature of the code, the EC decided that the EU should not fund nanoresearch whenever it 'could involve the violation of fundamental rights or fundamental ethical principles' (EC 2008, 9). Accordingly, the nanotechnologies action plan, launched in 2009, subjected research and development proposals submitted for funding under FP7 to a thorough ethical review. They should be funded only 'if they address ethical issues adequately and meet the necessary Community and national requirements - including the EU Charter of Fundamental Rights' (EC 2009, 6).

The novelty and uncertainties involved in this area, either with respect to its scope or to its potential ethical and legal as well as physical impacts, surface as primary motivations for the EC option to combine soft law with self-regulation (EC 2007d, 4, 5). By the same token, drawing lessons from the highly contested regulatory history of GMOs, the EU used this opportunity to open up and involve stakeholders in the debate on the appropriate regulatory principles for nano S\&T.

The European Parliament has considered proposals for specific regulations on the use of nanotechnologies in two fields with different outcomes: cosmetics and novel food. The Cosmetic Products Regulation was adopted on 30 November 2009 and regulates the use of nanomaterials ${ }^{21}$. In contrast, the Parliament and the Council failed to reach agreement on an update to the Novel Foods Regulation to include nanomaterials definition and labelling ${ }^{22}$. In the

\footnotetext{
19 'Calls for the application of a duty of care for manufacturers that wish to put nanomaterials on the market; and calls on them to adhere to the European code of conduct for responsible nanosciences and nanotechnologies research' (10), European Parliament resolution of 24 April 2009 on regulatory aspects of nanomaterials, (2010/C 184 E/18), P6_TA (2009) 0328.

${ }^{20}$ On the EGE and the blurring of normative ethical and legal orders cf. Plomer 2008, 845, 846: 'the EGE's Opinions have historically drawn on a mixture of ethical principles and fundamental (legal) principles contained in a variety of sources. (...) The danger lies in the blurring of normative ethical and legal orders in areas which are already potentially highly charged' as happens with S\&T and on the EGE as a 'grey governance' institution cf. Flear, Vakulenko 2010, 684.

${ }^{21}$ Regulation (EC) No 1223/2009 (the Regulation will be applicable, for the most part, from July 2013). The Regulation includes a definition of 'nanomaterials' in Article 2, 1, k. A very accurate regulatory overview at the time of writing can be found at "Developments in Nanotechnologies Regulation and Standards 2010", No. 2, June 2010, www.observatorynano.eu/project/filesystem/files/ObservatoryNano_Nanotechnologies_RegulationAndStan dards_2010.pdf.

${ }^{22}$ Regulation (EC) No 258/97.
} 
first case, a hard law instrument was adopted following the co-decision procedure between the European Parliament and the Council following the impact assessments and public consultation procedures carried by the Commission, and in the second, the novelty and complexity of the subject-matter may account for the failure to reach an agreement on the reviision of the Novel Foods Regulation.

Soft law has also provided a key regulatory tool for human cloning. The European Parliament's resolution on human cloning, of 2000, reflected the Parliament's recognition of the need to address a new technology at an initial stage of development, raising highly sensitive ethical dilemma.

Cloning, a technology in an experimental phase, is indeed one of the most controversial issues in the bioethics debate today; a debate that is far from over. 'Cloning is the process of producing 'genetically identical' organisms. It may involve division of a single embryo, by prompting a fertilised egg to split in two, in which case both the nuclear genes and the small number of mitochondrial genes would be 'identical', or it may involve nuclear transfer, in which case only the nuclear genes would be 'identical' (GAEIB 1997, p. 2) ${ }^{23}$. The GAEIB ${ }^{24}$ accepted that research on nuclear transfer could have important therapeutic applications for the development of appropriate stem cell cultures for the repair of human organs, and could also provide insights into ways to induce the regeneration of damaged human tissues ${ }^{25}$. The GAEIB also accepted non-therapeutic research on human embryos involving nuclear substitution as long as it was conducted under strict licence and only with 'the objective either to throw light on the cause of human disease or to contribute to the alleviation of suffering, ${ }^{26}$. In contrast the European Parliament argued that reproductive and therapeutic cloning should equally be banned since any relaxation of the law 'will lead to pressure for further developments in embryo production and usage, 27 . Cloning involving the creation of human embryos for research purposes poses a 'profound ethical dilemma' and 'irreversibly crosses a boundary in research

\footnotetext{
23 This distinction is relevant in considering the implications of cloning (GAEIB 1997, p. 4). The first method is the simpler way of creating a clone. This is a technique already used for stock breeding which, together with somatic cell nuclear transfer, are the main techniques of reproductive cloning, or simply put, the use of technology to create a living copy of an existing human being. The second method, cloning by nuclear replacement, or therapeutic cloning, is a technology whereby embryonic stem cells can be harvested for curing diseases and possibly to replace organs and tissues.

${ }^{24}$ The Group of Advisers on the Ethical Implications of Biotechnology to the European Union preceded the European Group on Ethics.

${ }^{25}$ GAEIB, Ethical Aspects of Cloning Techniques, 5.

${ }^{26}$ GAEIB, Ethical Aspects of Cloning Techniques, 6. In the same vein, Dir 98/44/EC off 6 July 1998 on the legal protection of biotechnological inventions prohibits the granting of patents on processes for cloning human beings and uses of human embryos for industrial or commercial purpose (paragraphs 41 and 42) as contrary to the purposes of public order and morality (Art 5, No 1 and 6). However, such exclusion did not affect 'inventions for therapeutic or diagnostic purposes which are applied to the human embryo and are useful to it' (paragraph 42 and Art 6, No 2).

${ }^{27}$ European Parliament Resolution on Human Cloning, paragraph $\mathrm{H}$.
} 
norms', the Parliament believed ${ }^{28}$. While recognising that 'the undoubted need for medical research resulting from advances in knowledge of human genetics must be balanced against strict ethical and social constraints, ${ }^{29}$, the European Parliament resolution on human cloning proclaimed that 'there should be a universal and specific ban at the level of the United Nations on the cloning of human beings at all stages of formation and development ${ }^{\circ 30}$. To justify this ban, the European Parliament's resolution emphasised the value of 'human dignity and the consequent value of each human being, ${ }^{31}$. Article 3 of the EU Charter of Fundamental Rights eventually prohibited the reproductive cloning of human beings, but left out therapeutic cloning (Article 3, paragraph 2, d). Hard law was therefore employed to the extent that a social and political consensus existed in Europe, indeed an early and rather broad one, on the rejection of human cloning for reproductive purposes. Accordingly, the $7^{\text {th }}$ framework programme on research and development forbade research involving reproductive cloning ${ }^{32}$.

Differences of opinion among EU institutions in this regard reflect the imprecision of the right to human integrity and of the principle of human dignity and the consequent passing on of their practical definition to EU institutions, which show varying degrees of sensitivity to the ethical values at stake ${ }^{33}$.

In contrast to both nanosciences and technologies, and human cloning, the information technology of biometrics, which rose to the centre of techno-juridical and techno-political debates following ' $9 / 11$ ', has been regulated predominantly through hard law instruments, particularly Regulation (EC) No. 2252/2004, of 13 December 2004, on standards for security features and biometrics in passports and travel documents issued by Member States, and Directive 95/46/EC, of 24 October 1995, on the protection of individuals with regard to the

\footnotetext{
${ }^{28}$ European Parliament Resolution on Human Cloning, paragraph 2 and paragraph E. This was in line with trends in EU research and development policy. Cf. Decision 1982/2006/EC, of 18 December 2006, $7^{\text {th }}$ Framework Programme, Art 6 ('Ethical principles'), paragraph 2: 'The following fields of research shall not be financed under this Framework Programme: research activity aiming at human cloning for reproductive purposes'; Dec 1513/2002/EC, of 27 June 2002, $6^{\text {th }}$ Framework Programme, underlining that fundamental ethical principles shall be respected, including the principles highlighted in the Charter of Fundamental Rights and in the Council of Europe Convention on Human Rights and Biomedicine (Oviedo, 1997) and the Additional Protocol on the Prohibition of Cloning Human Beings (Paris, 1998) (Annex I); and Council Decision 2002/834/EC, of 30 September 2002, 'The following fields of research shall not be financed under this programme: research activity aiming at human cloning for reproductive purposes' (Annex I).

${ }^{29}$ European Parliament Resolution on Human Cloning, paragraph B.

${ }^{30}$ European Parliament Resolution on Human Cloning, paragraph 10.

${ }^{31}$ European Parliament Resolution on Human Cloning, paragraph A.

32 Decision 1982/2006/EC, of 18 December 2006, $7^{\text {th }}$ framework programme, Article 6; Decision 1513/2002/EC, of 27 June 2002, $6^{\text {th }}$ Framework Programme, Annex I; and Decision 2002/834/EC, of 30 September 2002, Annex I.

${ }^{33}$ Recent news about discussions in the EU regarding novel food (meat and milk) produced through animal cloning confirms the opposing views of the Parliament and the Council: whereas the Parliament rejected their commercialization, the Council of Ministers of Agriculture favoured the assignment of the status of novel food to such products. Cf. 'Des aliments issues du clonage dans l'assiette anglaise', Le Monde, 7 August 2010, 4.
} 
processing of personal data and on the free movement of such data. Biometrics relies on human characteristics such as face features, fingerprints, hand impressions, iris recognition or DNA to verify the identity of an individual. Today, biometrics is central to national and international security and immigration policies in Europe and has also become increasingly important economically as it is increasingly employed to control the access of workers, students, and other categories of people to various organisations (IPTS 2005, 80-87).

Although biometrics is not a totally secure identification technique according to the experts, it has not caused the same uncertainty or social unrest as other new technologies, which involve risks for man and the environment such as biotechnologies or even nanotechnologies. In fact, biometrics technologies allow data to be collected on the intimate features of individuals, yet this does not seem to have been perceived widely as a threat to individual liberty. In the EU context, biometrics was furthered primarily for security purposes following the US government's pressure on the EU to adopt the biometrical passport for EU citizens travelling to the USA. Both the urgency of its implementation and its background in security policy meant that biometrics would be more likely to be framed by a hard law instrument.

In some way biometrical data protection also shows how hard law may call upon selfregulation as a complementary regulatory tool. The Data Protection Directive, rendered applicable to biometrical data to be processed in the context of passports and travel documents by Regulation No. 2252/2004 (Article 4), remits to self-regulation in Article 27, 1. Codes of conduct should be encouraged by Member States as a means of contributing to the proper implementation of the Directive. Examples of such codes of conduct are the Irish Biometrics Organisation's Code of Ethics and the International Biometrics \& Identification Association (IBIA)'s Ethics Statement ${ }^{34}$. A recommendation for a code of conduct for FP7 researchers on medical and biometric data was also put forth by the EU-funded ETHICAL project with specific guidelines for research projects funded by the FP7 involving government, industry and international data sharing (Menevidis et al. 2011).

The preference for hard law over soft law and self-regulation as regulatory tools for biometrics may, however, account for the insufficiency of procedural arrangements for the participation of the public or citizens. 'The dialogue to date has been heavily influenced by commercial interest and political aspirations', and 'there has been remarkably little genuine consultation with citizens on a matter which will have a significant impact upon society', a report prepared for the EC admitted (Ashbourn 2005, 21).

\footnotetext{
${ }^{34}$ Both codes have been adopted by not-for-profit trade associations, and proclaim the principles of safeguarding the public, respect for competitive technologies, accountability in marketing, legitimacy and free trade. See www.ibo.ie/code of ethics.php; www.ibia.org/association/ethics-statement/.
} 
A somewhat similar path has been followed previously for genetically modified organisms (GMOs). GMO regulation has developed in the EU over the last two decades mainly by way of EU legislation, i.e. directives and regulations. As a technology already employed in field experimentation and starting to be used for agro-industrial production, hard law and formal institutional procedures under the EU and Member States offered the appropriate means of controlling GMO research and applications in agriculture and food production. Starting with Directives 90/220/EEC and 90/219/EEC, the EU regulatory framework for GMOs now includes Directive 2001/18/EC on the deliberate release of GMOs into the environment, Regulation $1829 / 2003$ on genetically modified food and feed and Regulation 1830/2003 concerning the traceability and labelling of genetically modified organisms and the traceability of food and feed products produced from genetically modified organisms.

However, this case also shows the role that self-regulation and soft law can play in anticipating hard law, either because the topics are sensitive or tend to be addressed first in a flexible non-binding manner, or due to the novelty of the subject matter ${ }^{35}$. A well-known anticipatory move of this kind were the pioneering Asilomar Conference held in 1975 when scientists drew up a self-regulatory instrument ${ }^{36}$, admitting the uncertainties involved in genetic research and the need to have it regulated. In the European space, prior to Directive 90/220/EEC, genetic research and engineering was the subject of a number of written questions to the European Parliament. Two relevant resolutions were adopted, the 'Resolution on the effects of the use of biotechnology on the European farming industry' $(1987)^{37}$ and the 'Resolution on the ethical and legal problems of genetic engineering' (1989) ${ }^{38}$.

In sum, soft law and self-regulation were used at the earliest stages, paving the way to legislation once research and technological applications and their impacts on the economy and society had become visible.

Yet, remarkably, soft law has been the main option for regulating the coexistence of genetically modified crops with conventional and organic crops. The Commission Recommendation of 13 July 2010 on guidelines for the development of national co-existence measures to avoid the unintended presence of GMOs in conventional and organic crops (2010/C 200/01), replacing Recommendation of 23 July 2003 (2003/556/EC), recognized that 'Member States need sufficient flexibility to take into account their regional and national specificities and

\footnotetext{
${ }^{35}$ New developments in food law have seen the expansion of codes of conduct. The aquaculture industry constitutes another example of this self-regulatory trend: http://www.piscestt.com/consumer/codes/feapintro en.asp.

${ }^{36}$ Summary Statement of the Asilomar Conference on Recombinant DNA Molecules, 20 May 1975, http://profiles.nlm.nih.gov/QQ/B/C/G/D/ /qqbcgd.pdf.

37 Official Journal C 076, 23/03/1987, p. 0022.

38 Official Journal C 096, 17/04/1989, p. 0165.
} 
the particular local needs' (EC 2010, paragraph 7). In this instance, European soft law paved the way for national rather than European legislation, leaving it up to individual Member States to choose the regulatory tools (Directive 2001/18/CE, Article 26 a). Recommendation 2003/556/EC stated that 'Member States may prefer to explore the use of different policy instruments, e.g., voluntary agreements, soft-law approaches and legislation' (Recommendation 2003/556/EC, p. 10$)^{39}$.

The Commission's reports on the implementation of coexistence measures help to clarify the ratio behind the recommendations ${ }^{40}$. Lack of knowledge of the impract of coexistence and of coexistence measures and the 'need to conclude the process of implementing national coexistence measures' were presented as justifications for not developing a 'dedicated harmonized legislative approach' (EC 2006, 4 and 10). In this instance, soft law has been employed by the EC as a coordinating method of national measures. Despite the use of recommendations as regulatory tools, hard law continues to provide, not only their underlying basis (particularly, Directive 2001/18/EC), but also their follow-up. The EC underlined the compulsory character of the proposed measures, and even raised doubts about compliance of Member States with the Commission's 'advice' (EC 2006, 6). 'National coexistence measures cannot introduce requirements to protect the environment which go beyond the provisions laid down in Community legislation' (EC 2006, 5).

This shows how these recommendations as "soft law, ${ }^{41}$ have in fact been invested with some degree of binding force ${ }^{42}$.

\footnotetext{
${ }^{39}$ Voluntary codes or non-binding codes of good practice have been chosen by a minority of countries as policy instruments to address coexistence at national level. Spain and the Netherlands are among these countries. Cf. Commission Staff Working Document, Annex to the Commission Report on the implementation of national measures on the coexistence of genetically modified crops with conventional and organic farming (SEC (2006)313), p. 17 and Commission Report on the implementation of national measures on the coexistence of genetically modified crops with conventional and organic farming (COM(2006)104 final), p. 7.

${ }^{40}$ The Commission will report in 2012 on Recommendation of 13 July 2010 (Report of 2 April 2009 on the coexistence of genetically modified crops with conventional and organic farming, COM (2009)153 final, p. 11).

${ }^{41}$ Commission Recommendation of 13 July 2010 underlines that the present guidelines take the form of non-binding recommendations' (paragraph 1.4). Commission Recommendation 2003/556/EC of 23 July 2003 has the same phrasing (paragraph 1.5).

42 The legal effect of recommendations was addressed by the $\mathrm{ECJ}$ in the Grimaldi case regarding national courts: 'national courts are bound to take recommendations into consideration in order to decide disputes submitted to them'. See Case C-322/88, Grimaldi [1989] ECR I-4407, paragraph 18. Cf. Ştefan 2008, 767.
} 


\section{Conclusion}

As we pointed out in the introduction, there is a wide belief that soft law, together with voluntary self-regulation, provide suitable regulatory tools for S\&T, possibly better tools than 'hard law', to cope with the need for both flexibility and adjustment to novelty and prevailing uncertainties. There are indeed some plausible reasons for embracing soft law and for encouraging self-regulation in S\&T. Does the above review confirm that belief? What tendencies can one derive from the analysis and comparison of the EU regulatory response to various emerging technologies?

The EC recommendation on a code of conduct for Nanos S\&T indeed provides a paradigmatic illustration of soft law as a means of promoting self-regulation in an emerging scientific and technological area where doubts and uncertainties persist about the scope of the area itself, potential applications, and ethical and social implications generally. For the EU institutions that launched it, the recommendation and the code of conduct also represented a conscious, deliberate 'effort to integrate the societal dimension into R\&D' and 'to involve all stakeholders'. In turn, the prohibition of reproductive human cloning in the EU Charter of Fundamental Rights may be understood in the light of the wide social and political consensus already existing in that regard, though this consensus was confined to human cloning for reproductive purposes. Yet, soft law in the form of a European Parliament resolution was the regulatory tool used to address remaining uncertainties about the possible therapeutic applications of human cloning.

EU regulation of biometrics relies mainly on hard law instruments. Biometrics is a security technology widely employed for social control by the police and security services, which may explain the preference for legislation, and incidentally the alleged lack of transparency and public involvement in the decision making process leading to the adoption of the biometrical passport regulation.

Then the question comes out again: are soft law and self-regulation preferred by EU institutions as regulatory tools for emerging sciences and technologies or are they operating mostly as preparatory stages or complementary tools to hard law? Is soft law being used chiefly to address ethically or socially sensitive or controversial topics in science and technology? And is soft law working as a means to a more democratic governance of science and technology?

We conclude that soft law is being used primarily as a preparatory or opening phase for hard law. In its turn, self-regulation is being promoted by EU institutions as a complementary means to further the implementation of legislation: in other words, they both work as preliminary or complementary stages of hard law; besides, they are either grounded in or 
dependent upon EU legislation, the latter yielding them their authoritative force. As a matter of fact, although European institutions' discourse suggests a preference for alternative forms of regulation, hard law instruments appear to prevail.

While soft law provides a response to the speed of change and the need to accommodate the societal and ethical dimensions at stake in emerging sciences and technologies, doubts remain concerning its effectiveness as a regulatory instrument. Moreover, the growing use of soft law approaches, self-regulation and co-regulation as governance instruments seems to create a paradox: although they are often designed to enhance more active participation and dialogue with civil society, and ultimately to increase EU's legitimacy, they are also perceived as lacking transparency and accountability ${ }^{43}$. In the European regulation of S\&T balancing governance and the effective participation of citizens, on the one hand, and the dangers of a deregulatory and undemocratic movement, on the other, is not an easy task ${ }^{44}$. Finding the right balance between soft and hard law instruments, governance and citizen participation, and hard law democratic enactment, particularly to protect fundamental human rights, is a major challenge confronting European S\&T policy ${ }^{45}$. The certainty required for contentious fields, combined with concerns about the lack of transparency surrounding some soft law instruments and suspicions about the influence of powerful economic stakeholders may go some way towards explaining the prevalence of hard law instruments in S\&T regulation.

${ }^{43}$ Cf. Verbruggen 2009, 431 and Scott, Trubek 2002.

${ }^{44}$ The 'two-way negotiation' entails the idea of dialogue, already expressed in Article 11(2) of the TEU stating that institutions shall dialogue with civil society (Flear, Vakulenko 2010,670).

${ }^{45}$ E.g. the Horizon 2020 Strategy, http://ec.europa.eu/research/horizon2020/index_en.cfm?pg=home. 


\section{References}

Andorno, R., (2007), "The Invaluable Role of Soft Law in the Development of Universal Norms in Bioethics", http://www.unesco.de/1507.html.

Ashbourn, J., (2005), "The Social Implications of the Wide Scale Implementation of Biometric and Related Technologies", Background paper for the Institute of Prospective Technological Studies, DG Joint Research Centre, European Commission.

Bowman, D.M., Hodge, G.A., (2007), “A Small Matter of Regulation: An International Review of Nanotechnology Regulation”, The Columbia Science and Technology Law Review, Vol. VIII, pp. 1-36.

Carbonnier, J., (1965), "Le grandi ipotesi della sociologia teorica del diritto", Quaderni di Sociologia, Torino, Vol. XIV, $\mathrm{n}^{\circ} 3$.

Carbonnier, J., (1979), Sociologia Jurídica, Coimbra: Livraria Almedina.

Delmas-Marty, M., (2002), Towards a Truly Common Law: Europe as a Laboratory for Legal Pluralism, Cambridge: Cambridge University Press.

Di Robilant, A., (2006), "Genealogies of Soft Law", The American Journal of Comparative Law, n. ${ }^{\circ}$ 54, pp. 499-554.

Fauré, C., (2011), Ce que Déclarer des Droits Veut Dire, Paris: Les Belles Lettres.

Flear, M.L., Vakulenko, A., (2010), “A Human Rights Perspective on Citizen Participation in the EU's Governance of New Technologies", Human Rights Law Review, Vol. X, n. ${ }^{\circ} 4$, pp. 661688.

Gaeib, (1997), "Ethical Aspects of Cloning Techniques", 28 May 1997, 2, http://ec.europa.eu/european_group ethics/docs/opinion9 en.pdf.

Gersen, J.E., Posner, E.A., (2008), “Soft Law”, Public Law and Legal Theory Working Paper $\mathrm{N}^{\mathrm{o}}$. 213, The Law School, The University of Chicago, http://www.law.uchicago.edu/academics/publiclaw/index.html. 
Héritier, A., (2001), “The White Paper on European Governance: A Response to Shifting Weights in Inter-institutional Decision-Making”, in Jean Monnet Working Paper N. ${ }^{\circ}$ 6/01, Symposium: Mountain or Molehill? A Critical Appraisal of the Commission White Paper on Governance, http://centers.law.nyu.edu/jeanmonnet/papers/01/011301.html.

Institute for Prospective Technological Studies (IPTS), (2005), "Biometrics at the Frontiers: Assessing the Impact on Society", Joint Research Centre, European Commission, pp. 80-87, http://ec.europa.eu/justice home/doc_centre/freetravel/doc/biometrics_eur215.85 en.pdf

Kurath, M., (2009), "Nanotechnology Governance, Accountability and Democracy in New Modes of Regulation and Deliberation", in Science, Technology \& Innovation Studies, Vol. 5, No. 2, pp. 87-110.

Menevidis, Z., Swartzman, S., Stylianidis, E. (2011), "Code of Conduct for FP7 Researchers on medical and biometric data privacy", in R. von Schomberg (ed.), Towards Responsible Research and Innovation in the Information and Communication Technologies and Security Technologies Fields, Luxembourg: Publications Office of the European Union, pp. 115-132.

Mörth, U. (2004), Soft Law in Governance and Regulation: An Interdisciplinary Analysis, Cheltenham, UK: Edward Elgar Publishing.

Mörth, U. (2005), "Soft Law and New Modes of EU Governance - A Democratic Problem?", http://www.mzes.unimannheim.de/projekte/typo3/site/fileadmin/research\%20groups/6/Papers SS oft $\% 20$ Mode/Moerth.pdf.

Nowotny, H., Scott, P., Gibbons, M. (2001), Re-Thinking Science: Knowledge and the Public in an Age of Uncertainty, London: Polity Press.

Plomer, A. (2008), "The European Group on Ethics: Law, Politics and the Limits of Moral Integration in Europe”, European Law Journal, Vol. XIV, n. ${ }^{\circ}$, November, pp. 839-859.

Reynolds, G.H. (2003), "Nanotechnology and Regulatory Policy: Three Futures", Harvard Journal of Law \& Technology, Vol. XVII, N. ${ }^{\circ}$ 1, pp. 179-210. 
Royal Society \& Royal Academy of Engineering, (2004), Nanoscience and Nanotechnologies: Opportunities and Uncertainties, London: The Royal Society \& The Royal Academy of Engineering, http://www.royalsoc.ac.uk/policy.

Scott, J., Trubek, D.M. (2002), "Mind the Gap: Law and New Approaches to Governance in the European Union”, European Law Journal, Vol. 8, N. ${ }^{\circ}$ 1, pp. 1-18.

Senden, L. (2004), Soft Law in European Community Law, Portland, Oregon: Hart Publishing.

Senden, L. (2005), "Soft law, Self-regulation and Co-regulation in European Law: Where Do They Meet?", Electronic Journal of Comparative Law, Vol. 9, http://www.ejcl.org.

Snyder, F., (1994), "Soft Law and Institutional Practice in the European Community", in S. Martin (ed.), The Construction of Europe: Essays in honour of Emile Noël, Dordrecht: Kluwer Academic Publishers, pp. 197-225.

Ştefan, O.A. (2008), "European Competition Law in European Courts: A Matter of Hard Principles?", European Law Journal, Vol. 14, N. ${ }^{\circ}$ 6, pp. 753-772.

Trubek, D.M., Cottrell, P., Nance, M. (2005), “'Soft Law', 'Hard Law', and European Integration: Toward a Theory of Hybridity”, University of Wisconsin Legal Studies Research Paper N. ${ }^{\circ}$ 1002, http://law.wisc.edu/facstaff/trubek/hybriditypaperapril2005.pdf.

Verbruggen, P. (2009), “Does Co-Regulation Strengthen EU Legitimacy?", European Law Journal, Vol. 15, N.o 4, July 2009, pp. 425-441.

Von Bernstorff, J. (2008), "The Changing Fortunes of the Universal Declaration of Human Rights: Genesis and Symbolic Dimensions of the Turn to Rights in International Law", The European Journal of International Law, Vol. XIX, N. ${ }^{\circ}$ 5, pp. 903-924.

Wellens, K.C, Borchardt, G.M. (1989), "Soft Law in European Community" Law", European Law Review, n. ${ }^{\circ} 14$, pp. 267-321. 


\section{EU legislation and policy documents}

Decision No. 1982/2006/EC of the European Parliament and of the Council of 18 December 2006 concerning the Seventh Framework Programme of the European Community for research, technological development and demonstration activities (2007-2013).

Directive 95/46/EC of the European Parliament and of the Council of 24th October 1995 on the protection of individuals with regard to the processing of personal data and on the free movement of such data.

European Commission (2000), Working Document 'Science, society and the citizen in Europe', SEC (2000) 1973.

European Commission (2001), 'White Paper on Governance', COM (2001) 428 final.

European Commission (2002), 'European Governance: Better lawmaking', COM (2002) 275 final.

European Commission (2003), Recommendation on guidelines for the development of national strategies and best practices to ensure the coexistence of genetically modified crops with conventional and organic farming (2003/556/EC).

European Commission (2005), Recommendation on the European Charter for Researchers and on a Code of Conduct for the Recruitment of Researchers, (2005/251/EC), http://ec.europa.eu/eracareers/pdf/am509774CEE_EN_E4.pdf.

European Commission (2006), Communication from the Commission to the Council and the European Parliament - Report of the implementation of the national measures on the coexistence of genetically modified crops with conventional and organic farming (COM (2006) 104 final).

European Commission (2007), 'Taking European Knowledge Society Seriously', Report of the Expert Group on Science and Governance to the Science, Economy and Society Directorate, Directorate-General for Research.

European Commission (2007b), Decision of 2 February 2007 establishing the European Research Council (2007/134/EC). 
European Commission (2007c), Consultation paper "Towards a Code for Responsible Nanosciences and Nanotechnologies Research", https://europa.eu/sinapse/sinapse/index.cfm?\&fuseaction=cmtypubdiscdetail.detail\&highlightso urce $=$.

European Commission (2007d), Detailed Analysis of Results from the Consultation on a 'Code of Conduct for Responsible Nanosciences and Nanotechnologies Research', http://ec.europa.eu/research/science-society/document_library/pdf_06/consultation-nanosinapse-feedback_en.pdf.

European Commission (2008), Commission Recommendation on a code of conduct for responsible nanosciences and nanotechnologies research, COM (2008) 424 final.

European Commission (2009), Communication 'Nanosciences and Nanotechnologies: An action plan for Europe 2005-2009. Second Implementation Report 2007-2009', COM(2009)607 final.

European Commission (2009b), Challenging Futures of Science in Society, Emerging Trends and cutting-edge issues, Report of the MASIS Expert Group. Brussels: European Commission. ftp://ftp.cordis.europa.eu/pub/fp $7 /$ sis/docs/sis masis report en.pdf.

European Commission (2010), Recommendation on 'guidelines for the development of national co-existence measures to avoid the unintended presence of GMOs in conventional and organic crops' (2010/C 200/01).

European Commission (2011), Decision of 12 January 2011 amending Decision 2007/134/EC establishing the European Research Council (2011/12/EU).

European Economic and Social Committee (2001), Opinion on 'the Commission Staff Working Paper, SEC(2000) 1973 "Science, society and the citizen in Europe"' (2001/C 221/25).

European Economic and Social Committee (2005), Information Report 'Current state of coregulation and self-regulation in the Single Market', CESE 1182/2004, 10.02.2005.

European Economic and Social Committee (2005b), Opinion on the 'Communication from the Commission: Towards a European strategy for nanotechnologies' (2005/C 157/03). 
European Economic and Social Committee (2006), Opinion on 'Better lawmaking' (2006/C 24/12).

European Parliament (2000), Resolution on human cloning (7 September 2000).

European Parliament (2007), Resolution on institutional and legal implications of the use of "soft law" instruments (4 September 2007).

European Parliament (2009), Resolution on regulatory aspects of nanomaterials, (24 April 2009).

Inter-institutional Agreement on Better Law Making (2003/C 321/1).

Regulation (EC) No 258/97 of the European Parliament and of the Council of 27 January 1997 concerning novel foods and novel food ingredients.

Regulation (EC) No 1223/2009 of the European Parliament and of the Council of 30 November 2009 on cosmetic products. 